\title{
PENGEMBANGAN MEDIA PEMBELAJARAN MATEMATIKA MENGGUNAKAN ADOBE FLASH PROFESSIONAL BERBASIS LITERASI UNTUK MENINGKATKAN KREATIVITAS SISWA
}

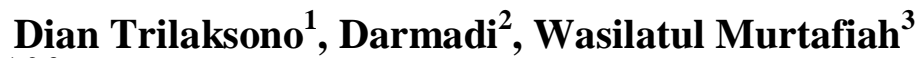 \\ ${ }^{1,2,3}$ Pendidikan Matematika, Universitas PGRI Madiun. \\ E-mail: $\quad$ dian3_laksono@yahoo.com ${ }^{1)}$ \\ darmadi7868482@yahoo.com $^{2)}$ \\ murtafiah.mathedu04@gmail.com ${ }^{3)}$
}

Received 26 June 2018; Received in revised form 17 September 2018; Accepted 24 September 2018

\begin{abstract}
This research is a research development that aims to know the validity, practicality, and effectiveness of learning media using Adobe Flash Professional based on literacy to improve student creativity and establish SMK Cendekia Madiun XI Banking as the subject of research with reference to 4D development model until the third stage, that is define, design, and develop. Instruments used in this research include validation sheet for instructional media, questionnaire response to measure the practicality of media, test result of learning result and questionnaire of student creativity to measure media effectiveness. The results of this study are as follows: 1) Learning media developed meet the criteria of validity and the average results obtained from the media validation questionnaire reached $85.42 \%$. 2) Learning media developed meet the criteria of practicality with the average results obtained from the questionnaire of student responses on field trials reached 81.25\%. 3) Learning media developed meet the criteria of effectiveness with the average results obtained from the average test results and the average score of student creativity questionnaires on field trials reached $82.95 \%$. Based on the results of this study can be concluded that the learning media using Adobe Flash Professional based literacy to improve student creativity developed by researchers worthy of use in learning.
\end{abstract}

Keywords: Adobe Flash Professional; Creativity; Learning Media; Literacy.

\section{PENDAHULUAN}

Pada era globalisasi ini sumber daya manusia yang mampu bersaing di dunia sangatlah dibutuhkan. Salah satu faktor yang mempengaruhi sumber daya manusia adalah pendidikan. Pendidikan memiliki peran penting untuk membentuk pribadi manusia yang berkualitas dan mampu bersaing diranah global. Permasalahan dalam dunia pendidikan erat hubungannya dengan proses pembelajaran. Untuk menunjang proses pembelajaran agar lebih maksimal siswa membutuhkan sumbersumber materi serta media pembelajaran yang dapat mempermudah pemahaman konsep pembelajaran, khususnya dalam proses pembelajaran matematika. Dalam proses pembelajaran, semakin banyak alat indera yang digunakan untuk menerima dan mengolah informasi semakin besar kemungkinan informasi tersebut dimengerti dan dipahami serta dapat dipertahankan dalam ingatan. Perbandingan pemerolehan hasil belajar melalui indera pandang dan indera dengar sangat menonjol perbedaannya. Kurang lebih $80 \%$ hasil belajar seseorang diperoleh melalui indera pandang (visual), dan hanya $15 \%$ diperoleh melalui indera dengar (audio), dan 5\% lagi dari indera yang lain (Rusman, 2013: 165). Hal ini sesuai dengan penelitian Darmadi (2009: 5-6) yang menyatakan bahwa prestasi belajar siswa pada pembelajaran dengan pemanfaatan PowerPoint dengan gaya belajar visual lebih baik dari pada gaya belajar auditorial dan kinestetik. 
Menurut Rusman (2013: 93) Pembelajaran merupakan proses interaksi antara guru dengan siswa, baik interaksi secara langsung seperti kegiatan tatap muka maupun secara tidak langsung, yaitu dengan menggunakan berbagai media pembelajaran. Media pembelajaran secara umum dapat diartikan sebagai alat bantu proses belajar mengajar. Salah satu media pembelajaran yang dapat digunakan adalah media pembelajaran yang menggunakan Teknologi Informasi dan Komunikasi (TIK). Pemanfaatan TIK dalam pembelajaran matematika dapat memvisualisasikan hal-hal abstrak atau imajinatif yang sulit diterima dalam pikiran siswa. Menurut Darmadi (2016: 681-682) terdapat beberapa tahap dalam memahami definisi atau konsep dengan visualisasi, seperti mengenali, membayangkan, memperlihatkan gambar definisi, memperlihatkan atribut definisi, dan menyimpulkan.

Sehubungan dengan hal tersebut dalam proses pembelajaran matematika hendaknya tertuju pada pengembangan media visual agar mampu meningkatkan kreativitas siswa dalam memecahkan masalah-masalah terkait konsep yang telah dipelajari. Menurut Suharnan (dalam Darmadi, 2015: 108) menjelaskan bahwa visualisasi dapat meningkatkan kinerja ingatan dan kemampuan berpikir kreatif. Menurut Semiawan (dalam Baihaqi, 2016: 207), kreativitas merupakan kemampuan untuk memberi gagasan baru dan bisa menerapkannya dalam pemecahan masalah.

Pembelajaran yang diberikan oleh guru harus mampu mendorong timbulnya keingintahuan siswa untuk melakukan penyelidikan, pemecahan masalah dan mampu memberikan jawaban atau cara-cara yang baru dalam menyelesaikan soal-soal. Seperti yang diungkapkan oleh Darmadi dan Handoyo (2016: 77) bahwa Guru matematika dituntut mempunyai kemampuan komunikasi matematika. Tetapi kenyataannya selama ini dalam pembelajaran matematika guru hanya menggunakan metode ceramah atau ekspositori, melihat dan mengamati dari satu buku paket saja, akibatnya siswa hanya pandai meniru contoh dan menjadi bingung ketika menyelesaikan soal.

Berdasarkan hasil wawancara dengan guru bidang studi matematika kelas XI Perbankan di SMK Cendekia Madiun, diperoleh gambaran bahwa kreativitas siswa di kelas XI Perbankan belum dikembangkan secara optimal, dengan ditandai hal sebagai berikut: (1) Siswa cenderung monoton, pegetahuan siswa hanya terbatas pada apa yang diperoleh dari guru dan satu sumber belajar yaitu buku paket, (2) Siswa kesulitan dalam mengembangkan pengetahuan yang diperoleh dari pembelajaran, (3) Siswa kurang berani mengungkapkan ide, gagasan, ataupun pendapat.

Dalam pengembangan pembelajaran guru harus mampu memilih dan memanfaatkan media yang ada sebaik mungkin, salah satunya yaitu buku, guru harus mendorong siswa untuk membaca buku-buku yang berkualitas, karena membaca sejalan dengan proses berpikir kritis yang memungkinkan siswa untuk kreatif dan berdaya cipta. Keterampilan nyata yang berkaitan dengan keterampilan membaca dan menulis disebut dengan literasi UNESCO (dalam Iswari \& Maryani, 2015: 62). Literasi dan kreativitas dapat dikembangkan untuk memberikan pengetahuan apa saja, baik sains, maupun kehidupan sosial. Sehingga bisa menjadi dasar untuk mengembangkan otak kiri (sains, logika, analisi, organisasi ide) dan otak 
kanan (bahasa, seni, imajinasi, kreativitas, kebebasan berpikir) secara seimbang. Menurut Abidin (2015: 23), pembelajaran literasi memiliki tujuan utama untuk memberikan kesempatan atau peluang kepada siswa untuk mengembangkan dirinya sebagai komunikator yang kompeten dalam multikonteks, multikultural, multimedia melalui pemberdayaan multiintelegensi yang dimilikinya.

Dalam kegiatan belajar mengajar di SMK diperlukan adanya suatu media pembelajaran yang inovatif dan kreatif. Sehingga sangat penting untuk mengembangkan media pembelajaran menggunakan Adobe Flash Professional berbasis literasi guna meningkatkan kualitas proses dan kreativitas siswa.

\section{METODE PENELITIAN}

Penelitian yang dilakukan oleh adalah jenis penelitian pengembangan (Research and Development). Menurut Sugiyono (2015: 30) metode penelitian dan pengembangan dapat diartikan sebagai cara ilmiah untuk meneliti, merancang, memproduksi dan menguji validitas produk yang telah dihasilkan. Model pengembangan media pembelajaran yang disarankan menurut Thiagarajan (dalam Trianto, 2011: 189) adalah model 4-D. Dalam penelitian ini menggunakan model 4-D dan hanya menerapkan langkah penelitian sampai pada tahap yang ketiga yaitu define, design, dan develop karena keterbatasan waktu dan biaya sehingga tahap disseminate tidak dilakukan. Kegiatan pada tahap define meliputi analisis potensi dan masalah, pengumpulan informasi, dan perumusan tujuan pembelajaran. Kegiatan pada tahap design meliputi penyusunan instrumen, pemilihan media, dan desain awal media pembelajaran. Kegiatan pada tahap develop meliputi validasi desain, revisi desain, uji coba terbatas, uji coba lapangan, analisi data media pembelajaran, output pengembangan.

Penelitian ini dilaksanakan di SMK Cendekia Madiun, yang terletak di Jln. Letkol Suwarno, Kanigoro, Kartoharjo, Kota Madiun. Penelitian dilaksanakan pada tahun ajaran 2017/2018 yang dimulai pada tanggal 25 sampai dengan 30 November 2017 dengan menyesuaikan jam pelajaran matematika di kelas XI Perbankan itu sendiri.Subjek penelitian yang diambil adalah siswa SMK Cendekia Madiun Kompetensi Keahlian Perbankan kelas XI tahun ajaran 2017/2018 dengan menetapkan 4 siswa sebagai responden uji coba terbatas dan 17 siswa sebagai responden uji coba lapangan.

Penelitian ini menggunakan sampel yang tidak dipilih secara random. Oleh karena itu desain uji coba penelitian ini menggunakan metode preexperimental design (non design) jenis one shot case study. Paradigma tersebut dapat ditafsirkan sebagai berikut: terdapat suatu kelompok yang diberi treatment/perlakuan, dan selanjutnya diobservasi hasilnya. Dalam penelitian ini variabel independennya adalah pembelajaran matematika dengan media pembelajaran menggunakan Adobe Flash Professional berbasis literasi. Sedangkan variabel dependennya adalah hasil yang diperoleh setelah melaksanakan pembelajaran, berupa hasil belajar dan kreativitas siswa.

Instrumen yang digunakan dalam penelitian ini antara lain, lembar validasi instrumen untuk mengukur kevalidan instrumen, lembar validasi media pembelajaran untuk mengukur tingkat validitas dari media yang dikembangkan, lembar angket respon siswa untuk mengukur tingkat kepraktisan dari media yang dikembangkan, soal tes hasil belajar dan 
lembar angket kreativitas untuk mengukur tingkat keefektifan dari media yang dikembangkan.

Untuk menguji kesesuaian media pembelajaran menggunakan Adobe Flash Professional berbasis literasi yang layak digunakan, perlu dilakukan analisis data setelah melakukan uji coba terbatas dan uji coba lapangan yang meliputi:

1. Analisis Kevalidan Media Pembelajaran

Untuk mengetahui kevalidan media dapat digunakan kriteria sebagai berikut (Akbar, 2013: 157).

Tabel 1. Kriteria Validitas

\begin{tabular}{|c|c|c|}
\hline No. & $\begin{array}{l}\text { Kriteria } \\
\text { Validitas }\end{array}$ & Tingkat Validitas \\
\hline 1. & $\begin{array}{l}85 \%<\mathrm{V} \leq \\
100 \%\end{array}$ & $\begin{array}{l}\text { Sangat Valid, atau } \\
\text { dapat digunakan } \\
\text { tanpa revisi }\end{array}$ \\
\hline 2. & $\begin{array}{l}70 \%<\mathrm{V} \leq \\
85 \%\end{array}$ & $\begin{array}{l}\text { Cukup Valid, atau } \\
\text { dapat digunakan } \\
\text { namun perlu } \\
\text { direvisi kecil }\end{array}$ \\
\hline 3. & $\begin{array}{l}50 \%<\mathrm{V} \leq \\
70 \%\end{array}$ & $\begin{array}{l}\text { Kurang Valid, } \\
\text { disarankan tidak } \\
\text { dipergunakan } \\
\text { karena perlu } \\
\text { direvisi besar }\end{array}$ \\
\hline 4. & $\begin{array}{l}01 \%<\mathrm{V} \leq \\
50 \%\end{array}$ & $\begin{array}{l}\text { Tidak Valid, atau } \\
\text { tidak boleh } \\
\text { dipergunakan }\end{array}$ \\
\hline \multicolumn{2}{|c|}{ Media } & pembelajaran \\
\hline $\begin{array}{l}\text { me } \\
\text { Prc } \\
\text { din } \\
\text { gal } \\
\text { dar }\end{array}$ & $\begin{array}{l}\text { ggunakan } \\
\text { essional } \\
\text { atakan valid } \\
\text { ingan menun } \\
70 \% \text { (Akbar, }\end{array}$ & $\begin{array}{l}\text { Adobe Flash } \\
\text { oerbasis literasi } \\
\text { jika hasil validitas } \\
\text { jukkan hasil lebih } \\
\text { 2013: 157). }\end{array}$ \\
\hline \multicolumn{3}{|c|}{ 2. Analisis Kepraktisan } \\
\hline \multicolumn{3}{|c|}{ Pembelajaran } \\
\hline \multicolumn{3}{|c|}{ Data yang dianalisis } \\
\hline \multicolumn{3}{|c|}{$\begin{array}{lll}\text { mengetahui } & \text { kepraktisan } & \text { media } \\
\text { pembelajaran } & \text { menggunakan } & \text { Adobe }\end{array}$} \\
\hline \multicolumn{3}{|c|}{$\begin{array}{l}\text { Angket respon siswa menggunakan } \\
\text { skala Likert dengan metode cheklist. }\end{array}$} \\
\hline
\end{tabular}

Skala Likert digunakan untuk mengukur sikap, pendapat, persepsi seseorang (Sugiyono, 2014: 93).

Media

pembelajaran

menggunakan Adobe Flash

Professional berbasis literasi dapat memenuhi kriteria kepraktisan media jika memenuhi kriteria $\geq 70 \%$ siswa secara klasikal memberikan respon positif (Saputro, 2011: 49-50).

3. Analisis Keefektifan Media Pembelajaran

Media

menggunakan Adobe Flash

Professional berbasis literasi dikatakan efektif jika siswa memenuhi ketuntasan belajar minimal $80 \%$ siswa yang secara klasikal memperoleh nilai minimal 75 (Hobri, 2010: 99) dan angket kreativitas siswa minimal $70 \%$.

Untuk menentukan keefektifan media pembelajaran menggunakan Adobe Flash Professional berbasis literasi dapat dihitung dari persentase ketuntasan belajar dan angket kreativitas siswa dengan menggunakan rumus.

$$
K=\frac{K B+P K}{2} \times 100 \%
$$

Keterangan :

$\mathrm{K}=$ Persentase keefektifan

$\mathrm{KB}=$ Persentase ketuntasan belajar

$\mathrm{PK}=$ Persentase kreativitas siswa

Selanjutnya persentase skor hasil keefektifan dianalisis sesuai dengan pedoman kriteria keefektifan menurut Sudjana (2014: 118).

Tabel 2. Kriteria Keefektifan

\begin{tabular}{cc}
\hline Persentase (\%) & $\begin{array}{c}\text { Tingkat } \\
\text { Keefektifan }\end{array}$ \\
\hline $90<\mathrm{K} \leq 100$ & Sangat efektif \\
\hline $80<\mathrm{K} \leq 90$ & Efektif \\
\hline $70<\mathrm{K} \leq 80$ & Cukup efektif \\
\hline $60<\mathrm{K} \leq 70$ & Kurang efektif \\
\hline $\mathrm{K} \leq 60$ & Tidak efektif \\
\hline
\end{tabular}




\section{HASIL PENELITIAN DAN PEMBAHASAN}

Produk yang dikembangkan dalam penelitian ini adalah media pembelajaran menggunakan Adobe Flash Professional berbasis literasi. Hasil penelitian yang telah dilakukan dijabarkan sebagai berikut.

1. Define (Pendefinisian)

Kegiatan observasi dan wawancara, didapatkan data sebagai berikut. a) Materi yang dipilih oleh dalam penelitian kali ini adalah materi barisan dan deret, yang terdapat di kelas XI perbankan semester gasal, b) Penelitian dilakukan di SMK Cendekia Madiun, khususnya di kelas XI Perbankan yang menggunakan kurikulum KTSP, c) Produk yang dikembangkan didasarkan pada potensi yang ada di SMK Cendekia Madiun dan belum pernah digunakan sebelumnya, sehingga dapat dengan mudah diterapkan, mengoptimalkan potensi yang ada dan memiliki daya guna yang tinggi, d) Produk yang dikembangkan harus dapat digunakan sebagai media pembelajaran yang layak dan menarik bagi siswa SMK Cendekia Madiun, dan harus didasarkan pada kurikulum yang diterapkan di sekolah.

\section{Design (Perancangan)}

Berdasarkan hasil dari kegiatan define, maka dipilih pengembangan media pembelajaran berupa media pembelajaran menggunakan Adobe Flash Professional berbasis literasi. Media yang dikembangkan menggunakan software komputer Adobe Flash Professional, hal ini dikarenakan melalui Adobe Flash Professional materi pembelajaran dapat dikemas dengan lebih menarik dan interaktif sehingga mampu meningkatkan kreativitas siswa.

Berikut desain awal media pembelajaran menggunakan Adobe Flash Professional berbasis literasi.

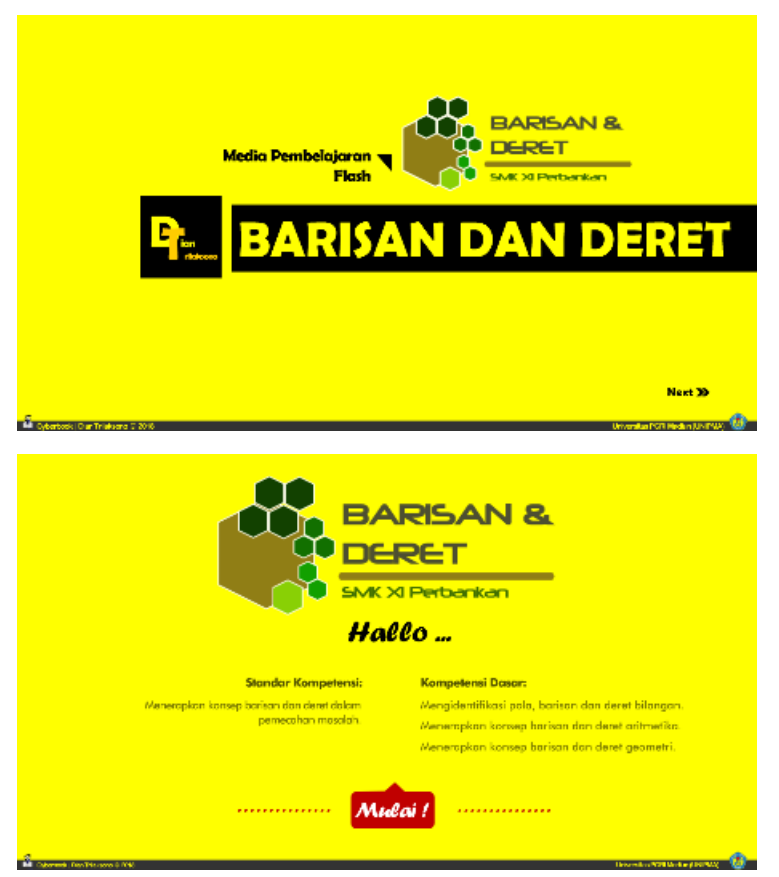

Gambar 1. Halaman Awal Media

Pembelajaran

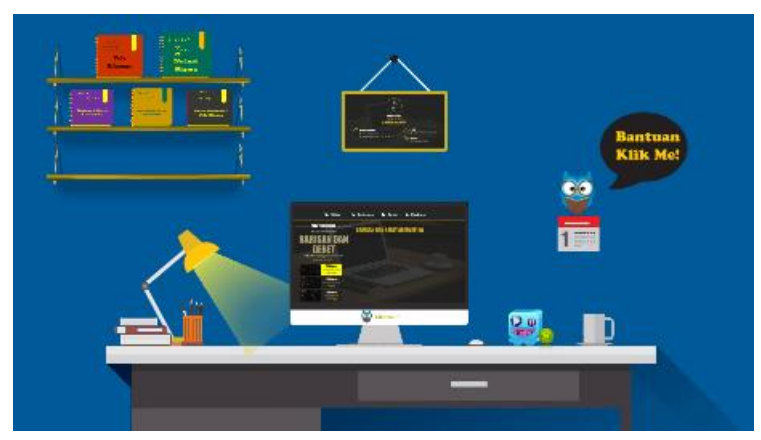

Gambar 2. Halaman Menu (Home) 
ISSN 2089-8703 (Print) Vol. 7, No. 2 (2018) 180-191

ISSN 2442-5419 (Online)

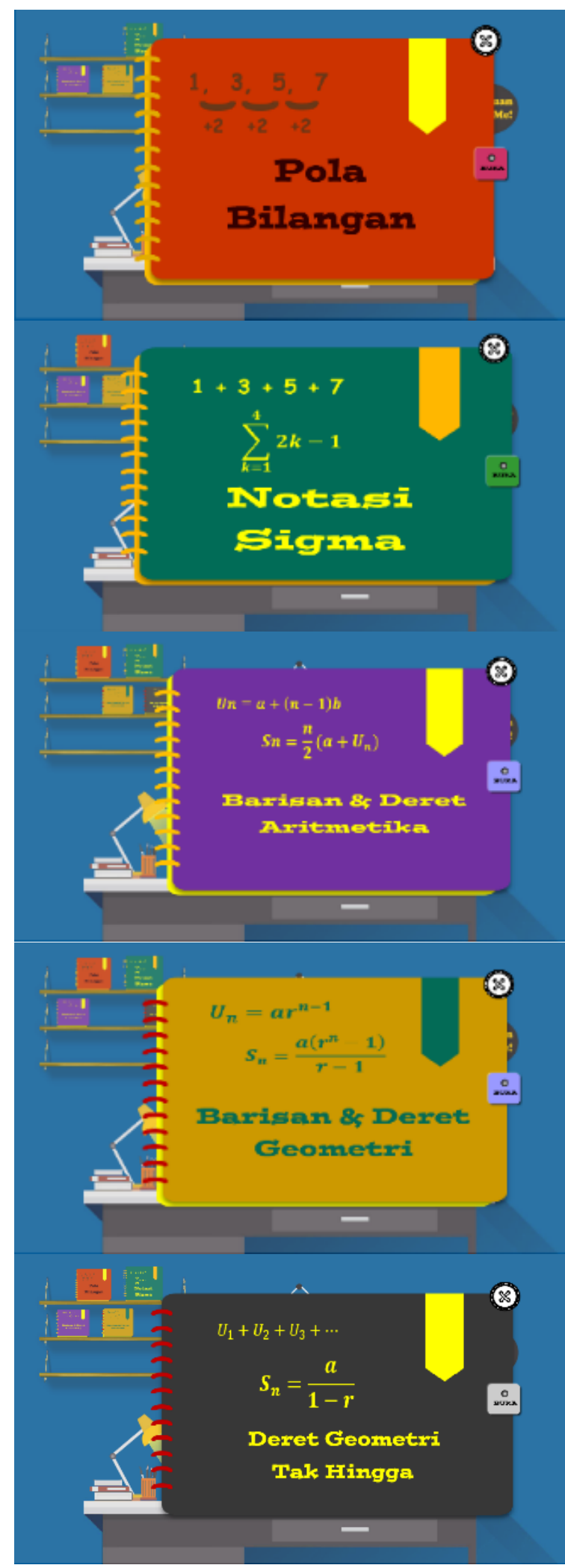

Gambar 3. Materi Pembelajaran

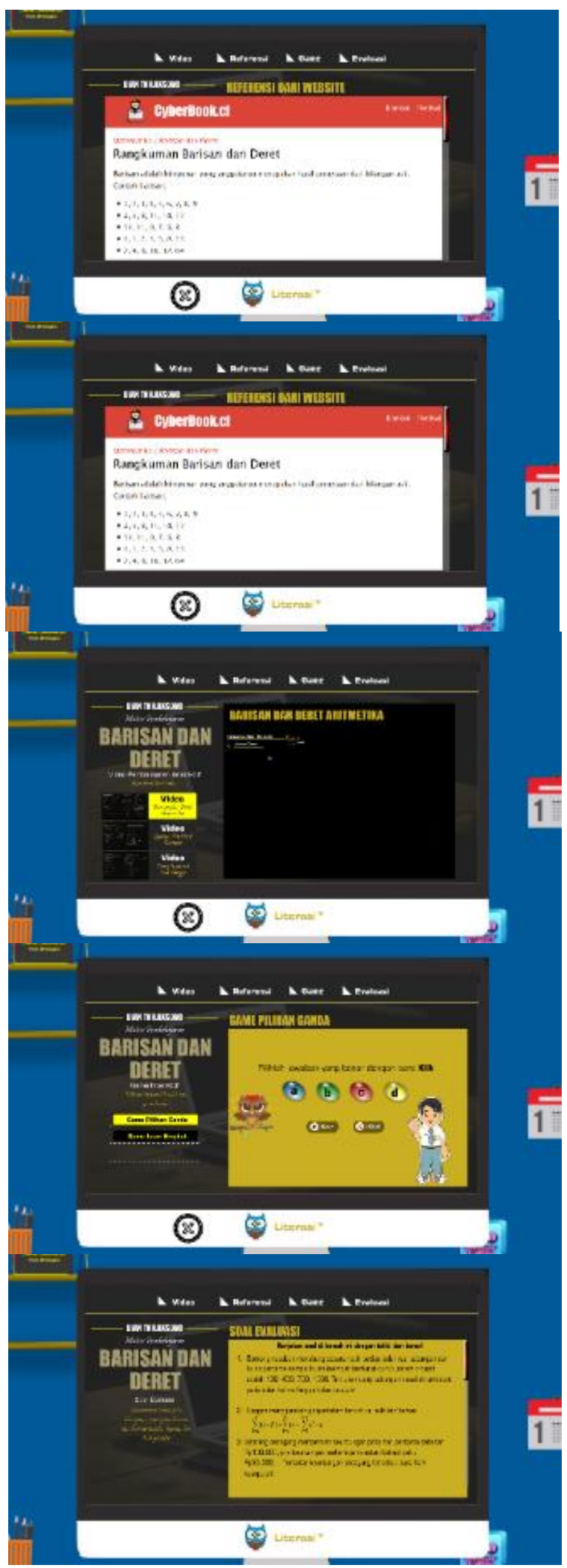

Gambar 4. Referensi Pembelajaran (literasi) 

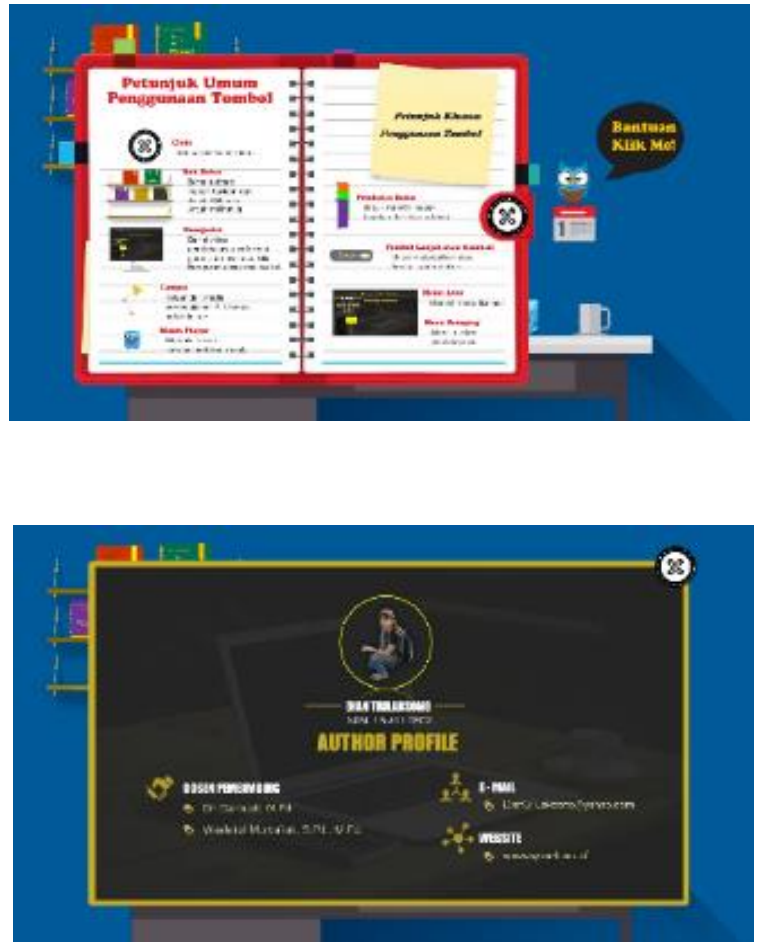

Gambar 5. Petunjuk Penggunaan dan profil pengembang

\section{Develop (Pengembangan)}

Tahap selanjutnya adalah tahap pengembangan. Secara lebih lanjut, kegiatan dalam tahap pengembangan ini dijabarkan sebagai berikut.

\section{Validasi Desain}

Pada uji validitas instrumen dalam penelitian ini melibatkan 3 orang validator untuk memvalidasi instrumen yang disusun. Validator uji validitas instrumen media pembelajaran menggunakan Adobe Flash Professional berbasis literasi ini, adalah: 1) Dosen pendidikan matematika Universitas PGRI Madiun, 2) Guru mata pelajaran matematika SMK Cendekia Madiun, 3) Guru bimbingan dan konseling SMK Cendekia Madiun.

Instrumen

dikatakan layak/valid jika rata-rata skor dari validator adalah $\geq 2,5$ dan tidak ada aspek yang yang mendapat skor 1 .
Adapun hasil validasi instrumen dalam penelitian ini, antara lain:

Tabel 3. Hasil Validasi Lembar Validasi Media

\begin{tabular}{cccccc} 
& \multicolumn{4}{c}{ Skor Aspek } & Rata- \\
\cline { 2 - 5 } Validator & $\mathbf{1}$ & $\mathbf{2}$ & $\mathbf{3}$ & $\mathbf{4}$ & $\begin{array}{c}\text { rata } \\
\text { Skor }\end{array}$ \\
\hline I & 0 & 0 & 9 & 39 & 3,81 \\
\hline II & 0 & 0 & 8 & 40 & 3,83 \\
\hline III & 0 & 0 & 15 & 33 & 3,69 \\
\hline
\end{tabular}

Berdasarkan Tabel 3, dapat disimpulkan bahwa lembar validasi media yang disusun layak digunakan.

Tabel 4. Hasil Validasi Angket Respon Siswa

\begin{tabular}{|c|c|c|c|c|c|}
\hline \multirow{2}{*}{ Validator } & \multicolumn{4}{|c|}{ Skor Aspek } & \multirow{2}{*}{$\begin{array}{c}\text { Rata-rata } \\
\text { Skor }\end{array}$} \\
\hline & 1 & 2 & 3 & 4 & \\
\hline I & 0 & 0 & 12 & 36 & 3,75 \\
\hline II & 0 & 0 & 8 & 40 & 3,83 \\
\hline III & 0 & 0 & 13 & 35 & 3,73 \\
\hline
\end{tabular}
disimpulkan bahwa angket respon siswa yang disusun layak digunakan

Tabel 5. Hasil Validasi Soal Tes Hasil Belajar

\begin{tabular}{cccccc}
\hline \multirow{2}{*}{ Validator } & \multicolumn{4}{c}{ Skor Aspek } & Rata- \\
\cline { 2 - 5 } & $\mathbf{1}$ & $\mathbf{2}$ & $\mathbf{3}$ & $\mathbf{4}$ & rata Skor \\
\hline I & 0 & 0 & 3 & 25 & 3,89 \\
\hline II & 0 & 0 & 9 & 19 & 3,68 \\
\hline III & 0 & 0 & 9 & 19 & 3,68 \\
\hline
\end{tabular}

Berdasarkan Tabel 5, dapat disimpulkan bahwa soal tes hasil belajar layak digunakan.

Tabel 6. Hasil Validasi Angket Kreativitas Siswa

\begin{tabular}{cccccc}
\hline \multirow{2}{*}{ Validator } & \multicolumn{3}{c}{ Skor Aspek } & Rata- \\
\cline { 2 - 5 } & $\mathbf{1}$ & $\mathbf{2}$ & $\mathbf{3}$ & $\mathbf{4}$ & $\begin{array}{c}\text { rata } \\
\text { Skor }\end{array}$ \\
\hline I & 0 & 0 & 11 & 41 & 3,79 \\
\hline II & 0 & 0 & 9 & 43 & 3,83 \\
\hline III & 0 & 0 & 12 & 40 & 3,77 \\
\hline
\end{tabular}




\begin{abstract}
Berdasarkan Tabel 6, dapat disimpulkan bahwa angket kreativitas siswa layak digunakan.

Rancangan produk (desain media) dari produk yang dikembangkan diserahkan kepada validator media untuk divalidasi. Validator media yang ditunjuk pada penelitian pengembangan ini terdiri dari 5 tenaga ahli sebagai pakar yaitu: 1) Guru multimedia SMK Cendekia Madiun sebagai ahli media. 2) Dosen Program Studi Pendidikan Matematika Universitas PGRI Madiun sebagai ahli media. 3) Guru matematika SMK Cendekia Madiun sebagai ahli materi. 4) Guru matematika SMK Cendekia Madiun sebagai ahli materi. 5) Dosen Program Studi Pendidikan Matematika Universitas PGRI Madiun sebagai ahli materi.
\end{abstract}

Tujuan dari validasi desain yang dilakukan ini adalah untuk meneliti apakah media pembelajaran yang dikembangkan benar-benar valid sehingga hasil penelitian yang dilakukan juga valid. Jika hasil dari validasi yang dilakukan belum dinyatakan valid oleh validator, maka wajib untuk melakukan revisi produk sesuai dengan saran yang diberikan oleh validator. Berikut hasil validasi media pembelajaran yang telah diberi penilaian oleh validator sesuai kriteria kevalidan.

Tabel 7. Hasil Validasi Media

\begin{tabular}{lccccc}
\multicolumn{6}{c}{ Pembelajaran } \\
\hline & I & II & III & IV & V \\
\cline { 2 - 6 } Tse & 38 & 48 & 44 & 39 & 36 \\
\hline Tsh & 48 & 48 & 48 & 48 & 48 \\
\hline V & 79,17 & 100 & 91,67 & 81,25 & $75 \%$ \\
& $\%$ & $\%$ & $\%$ & $\%$ \\
\hline V & \multicolumn{5}{c}{$85,42 \%$} \\
Akhir & Berdasarkan & analisis & hasil \\
\hline \multicolumn{5}{c}{ validasi dari Tabel } & 7 menunjukkan
\end{tabular}

bahwa media pembelajaran menggunakan Adobe Flash Professional berbasis literasi yang dikembangkan mendapat persentase validitas akhir sebesar $85,42 \%$ yang mana masuk dalam kategori valid dan siap diuji cobakan pada uji coba terbatas.

\section{Uji Coba Terbatas}

Uji coba terbatas melibatkan 4 siswa dari kelas XI Perbankan SMK Cendekia yang dipilih berdasarkan kemampuan kognitif yang terdiri dari 1 siswa berkemampuan kognitif tinggi, 2 siswa berkemampuan kognitif sedang dan 1 siswa berkemampuan kognitif rendah.

Berikut ini hasil pengisian angket respon siswa oleh siswa kelas XI Perbankan SMK Cendekia Madiun pada uji coba terbatas.

Tabel 8. Hasil Pengisian Angket Respon Uji Coba Terbatas

Jumlah skor Jumlah Persentase yang diperoleh skor ideal respon siswa

\begin{tabular}{ccc}
\hline 154 & 192 & $80,21 \%$ \\
\hline Dapat & dilihat pada Tabel 8
\end{tabular}

bahwa persentase respon siswa pada uji coba terbatas menunjukkan angka $80,21 \%$. Karena persentase respon siswa lebih dari 70\%, maka dapat disimpulkan bahwa respon siswa terhadap media pembelajaran menggunakan Adobe Flash Professional berbasis literasi pada uji coba terbatas adalah positif, sehingga memenuhi kriteria kepraktisan.

$$
\text { Media pembelajaran }
$$

menggunakan Adobe Flash

Professional berbasis literasi pada uji coba terbatas dikatakan efektif jika subjek penelitian memenuhi kriteria 
ketuntasan hasil belajar dan angket kreativitas siswa cukup.

Tabel 9. Hasil Ketuntasan belajar Uji coba Terbatas

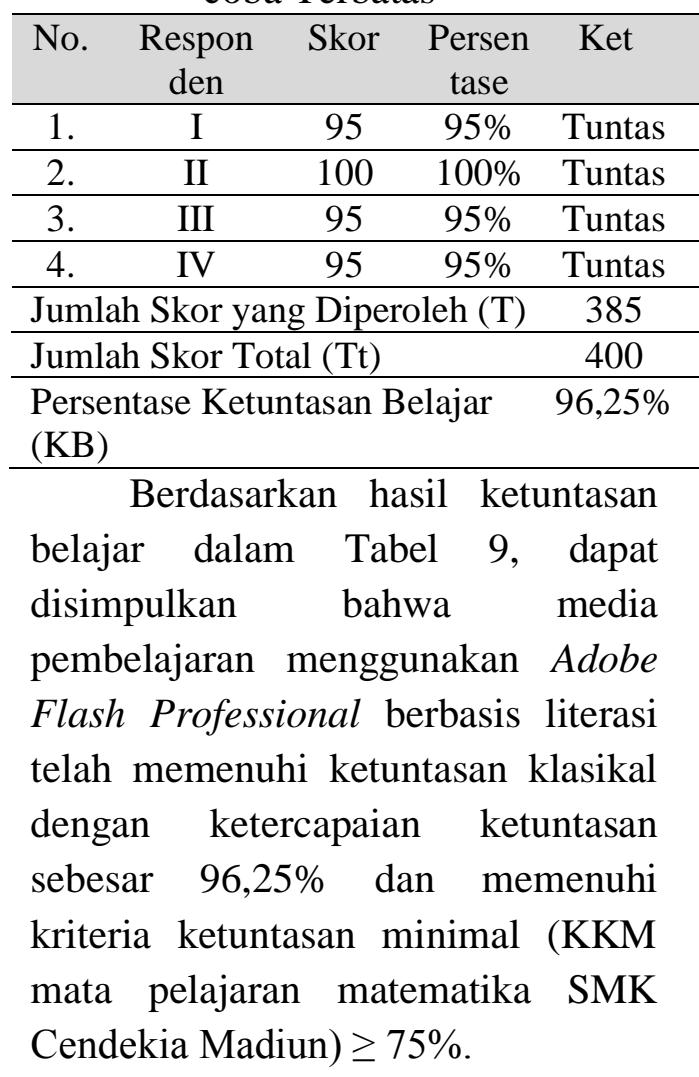

Tabel 10. Hasil Pengisian Angket Kreativitas Uji Coba Terbatas

\begin{tabular}{|c|c|c|c|c|}
\hline & \multicolumn{4}{|c|}{ Responden } \\
\hline & I & II & III & IV \\
\hline $\mathrm{N}$ & 41 & 40 & 35 & 41 \\
\hline \multirow{2}{*}{ PK } & 86,54 & 80,77 & 71,15 & 82,69 \\
\hline & $\%$ & $\%$ & $\%$ & $\%$ \\
\hline $\begin{array}{l}\text { Rata- } \\
\text { rata }\end{array}$ & \multicolumn{4}{|c|}{$80,29 \%$} \\
\hline
\end{tabular}

bahwa rata-rata persentase skor kreativitas siswa pada uji coba terbatas menunjukkan angka 80,29\%. Sehingga dapat disimpulkan bahwa media pembelajaran menggunakan Adobe Flash Professionalberbasis literasi pada uji coba terbatas siswa memiliki kreativitas belajar yang tinggi.

Berikut hasil keefektifan media pembelajaran menggunakan Adobe Flash Professional berbasis literasi pada uji coba terbatas yang dilihat dari tes hasil belajar dan angket kreativitas siswa.

Tabel 11. Hasil Analisis Keefektifan Media Pembelajaran pada Uji Coba Terbatas

\begin{tabular}{ll}
\hline KB & $96,25 \%$ \\
\hline PK & $80,29 \%$ \\
\hline Persentase & $88,27 \%$ \\
Keefektifan & \\
\hline \multicolumn{2}{r}{ Dapat dilihat pada Tabel 11 }
\end{tabular}
bahwa keefektifan pada uji coba terbatas menunjukkan angka 88,27\%. Sehingga dapat disimpulkan bahwa media pembelajaran menggunakan Adobe Flash Professional berbasis literasi pada uji coba terbatas memenuhi kriteria keefektifan dan siap digunakan pada uji coba lapangan.

Uji Coba Lapangan

Uji coba lapangan dilakukan di kelas XI Perbankan SMK Cendekia Madiun dengan jumlah siswa selain siswa yang dipakai dalam uji coba terbatas adalah 17 siswa.

Analisis kepraktisan media pembelajaran menggunakan Adobe Flash Professional berbasis literasi pada uji coba lapangan diperoleh dari hasil pengisian angket respon oleh siswa kelas XI Perbankan SMK Cendekia Madiun. Berikut ini hasil pengisian angket respon siswa oleh 17 siswa kelas XI Perbankan SMK 
Cendekia Madiun pada uji coba lapangan.

Tabel 12. Hasil Pengisian Angket Respon Uji Coba Lapangan

Jumlah skor Jumlah Persentase
yang diperoleh skor ideal respon siswa $663 \quad 816 \quad 81,25 \%$

Dapat dilihat pada Tabel 12 bahwa persentase respon siswa pada uji coba lapangan menunjukkan angka $81,25 \%$, sehingga memenuhi kriteria kepraktisan.

Media pembelajaran menggunakan Adobe Flash Professional berbasis literasi pada uji coba lapangan dikatakan efektif jika subjek penelitian memenuhi kriteria ketuntasan hasil belajar dan angket kreativitas siswa cukup.

Tabel 13. Hasil Ketuntasan Belajar Uji Coba Lapangan

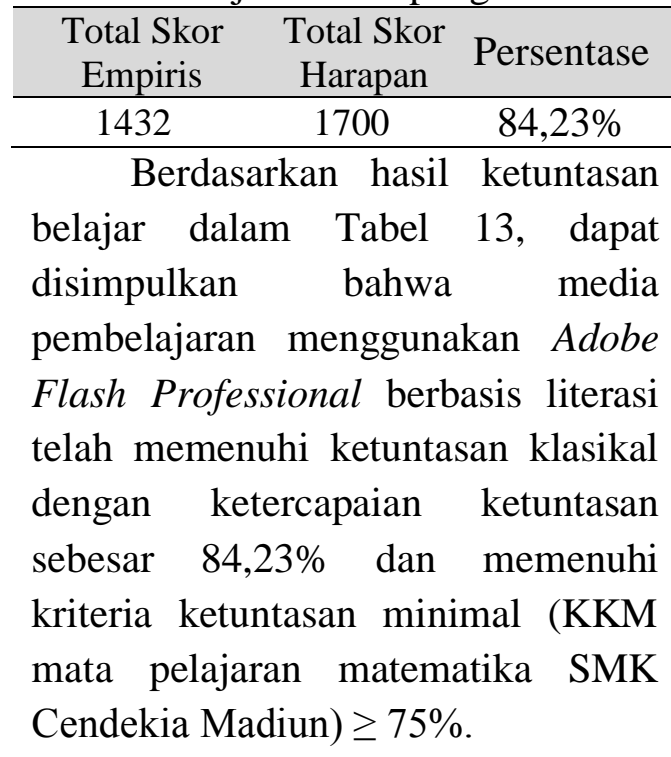

Tabel 13. Hasil Analisis Angket Kreativitas Siswa pada Uji Coba Lapangan

\begin{tabular}{ccc}
\hline $\begin{array}{c}\text { Jumlah skor } \\
\text { yang diperoleh }\end{array}$ & $\begin{array}{c}\text { Jumlah skor } \\
\text { ideal }\end{array}$ & PK \\
\hline 722 & 884 & $81,67 \%$ \\
\hline
\end{tabular}

Dapat dilihat pada Tabel 13 bahwa rata-rata persentase skor kreativitas siswa pada uji coba lapangan menunjukkan angka $81,67 \%$. Sehingga dapat disimpulkan bahwa media pembelajaran menggunakan Adobe Flash Professional berbasis literasi pada uji coba lapangan siswa memiliki kreativitas belajar yang cukup.

Berikut hasil keefektifan media pembelajaran menggunakan Adobe Flash Professional berbasis literasi pada uji coba lapangan yang dilihat dari tes hasil belajar dan angket kreativitas siswa.

Tabel 14. Hasil Analisis Keefektifan Media Pembelajaran pada Uji Coba Lapangan

\begin{tabular}{lll}
\hline KB & $84,23 \%$ \\
\hline PK & $81,67 \%$ \\
\hline Persentase & $82.95 \%$ \\
Keefektifan & & \\
\hline \multicolumn{1}{c}{ Dapat dilihat } & pada Tabel 14
\end{tabular}
bahwa keefektifan pada uji lapangan menunjukkan angka 82,95\%. Sehingga dapat disimpulkan bahwa media pembelajaran menggunakan Adobe Flash Professional berbasis literasi pada uji coba lapangan memenuhi kriteria keefektifan.

Berdasarkan hasil uji coba lapangan, dapat disimpulkan bahwa media pembelajaran menggunakan Adobe Flash Professional berbasis literasi untuk meningkatkan kreativitas siswa layak digunakan dalam proses pembelajaran matematika pada materi barisan dan deret, dengan persentase validitas $85,42 \%$ (cukup valid), persentase respon siswa $81,25 \%$ (respon positif), dan persentase keefektifan $82,95 \%$ (efektif). 


\section{KESIMPULAN DAN SARAN}

Dari hasil pengembangan media pembelajaran menggunakan Adobe Flash Professional berbasis literasi yang telah dilaksanakan, dapat disimpulkan sebagai berikut.

1. Tingkat validitas pengembangan media pembelajaran menggunakan Adobe Flash Professional berbasis literasi untuk meningkatkan kreativitas siswa memenuhi kriteria kevalidan dengan hasil rata-rata yang diperoleh dari angket validasi media mencapai $85,42 \%$.

2. Tingkat kepraktisan pengembangan media pembelajaran menggunakan Adobe Flash Professional berbasis literasi untuk meningkatkan kreativitas siswa memenuhi kriteria kepraktisan dengan hasil rata-rata yang diperoleh dari angket respon siswa pada uji coba lapangan mencapai $81,25 \%$.

3. Tingkat keefektifan pengembangan media pembelajaran menggunakan Adobe Flash Professional berbasis literasi untuk meningkatkan kreativitas siswa memenuhi kriteria keefektifan dengan hasil rata-rata yang diperoleh dari rata-rata tes hasil belajar dan rata-rata skor angket kreativitas siswa pada uji coba lapangan mencapai $82,95 \%$.

Berikut adalah saran terkait penelitian yang telah dilakukan.

1. Kreativitas siswa hanya diukur dengan menggunakan angket, sehingga hasil pengukuran tersebut dirasa kurang menunjukkan kreativitas siswa sesungguhnya dengan baik.

2. Media pembelajaran yang dikembangkan masih terdapat bug (kesalahan pemrograman).

\section{DAFTAR PUSTAKA}

Abidin, Y. (2015). Pembelajaran Multiliterasi: Sebuah Jawaban atas Tantangan Pendidikan Abad Ke-21 dalam Konteks Keindonesiaan. Bandung: PT Refika Aditama.

Akbar, S. (2013). Instrumen Perangkat Pembelajaran. Bandung: PT. Remaja Rosdakarya.

Baihaqi, M. (2016). Pengantar Psikologi Kognitif. Bandung: PT Refika Aditama.

Darmadi. (2009). Pengaruh Pemanfaatan PowerPoint dalam Pembelajaran Terhadap Prestasi Belajar Matematika Tingkat Sekolah Dasar Ditinjau dari Gaya Belajar Siswa. Jurnal Pendidikan, Volume 15 Nomor 01, Juni 2009, Program Studi Pendidikan Matematika, FPMIPA. IKIP PGRI Madiun.

Darmadi. (2015). Profil Berpikir Mahasiswa Laki-Laki Calon Guru Matematika dalam Memahami Definisi Formal Barisan Konvergen. Jurnal Math Educator Nusantara, Volume 01 Nomor 02, November 2015, Program Studi Pendidikan Matematika, FPMIPA. IKIP PGRI Madiun.

Darmadi \& Handoyo, B. (2016). Profil Berpikir Visual Mahasiswa Calon Guru Matematika Dengan Gaya Belajar Visual Dalam Menyelesaikan Masalah Trigonometri. Jurnal Math Educator Nusantara, Volume 02 Nomor 01, Mei 2016, Program Studi Pendidikan Matematika, FPMIPA. IKIP PGRI Madiun. 
Darmadi. (2016). Profil Berpikir Visual Level Pemrosesan Pembayangan Mental Mahasiswa Calon Guru Matematika Dalam Memahami Definisi Formal Barisan Konvergen.Makalah disajikan pada Seminar Nasional UNS, Jogjakarta, November 2016.

Hobri. (2010). Metodologi Penelitian Pengembangan: Aplikasi Pada Penelitian Pendidikan Matematika. Jember: Pena Salsabila.

Iswari, K. R. \& Maryani, I. (2015). Komik Sebagai Upaya Menanamkan Budaya Literasi Sains. (pp60-66). Prosiding Seminar Nasional Pendidikan Dasar SPS UPI: Membangun Imajinasi dan Kreativitas Anak Melalui Literasi. Bandung: Program Studi Pendidikan Dasar. Universitas Pendidikan Indonesia. (http://cyberbook.cf, diunduh 20 Oktober 2017).

Rusman. (2013). Belajar dan Pembelajaran Berbasis Komputer: Mengembangkan Professionalisme Abad 21. Bandung: Alfabeta, CV.

Saputro, A. T. (2011). Pengembangan Perangkat Pembelajaran Matematika dengan Media Visual Basic.Net 2008 pada Materi Lingkaran di Kelas VIIIB Mts. Negeri Krian Sidoarjo. Skripsi tidak diterbitkan. Fakultas Tarbiyah. Institut Agama Islam Negeri Sunan Ampel. (online), (http//digilib.unisby.ac.id, diunduh pada maret 2017).
Sudjana, N. (2014). Penilaian Hasil Proses Belajar Mengajar. Bandung. Rosdakarya.

Sugiyono. (2014). Metode Penelitian Kuantitatif Kualitatif dan $R \& D$. Bandung: Alfabeta.

Sugiyono. (2015). Metode Penelitian \& Pengembangan Research and Development. Bandung: CV Alfabeta.

Trianto. (2011). Mendesain Model Pembelajaran Inovatif-Progresif: Konsep, Landasan, dan Implementasinya pada Kurikulum Tingkat Satuan Pendidikan (KTSP). Jakarta: Kencana. 